\author{
Geology and geophysics
}

http://www.journalesgia.com

\title{
TRANSGRESSION AND REGRESSION OF CASPIAN PALEO-BASIN ON PALEOMAGNETIC DATA
}

\author{
Novruzov Z. ${ }^{1}$, Pilipenko O. ${ }^{2}$, Trubikhin V. ${ }^{3}$, Ismail-Zade T. ${ }^{1}$ \\ ${ }^{1}$ Geology and Geophysics Institute, ANAS \\ H.Javid Ave., 119, Baku, Azerbaijan, AZ1143; znovruz@yahoo.com \\ 2Institute of Physics of the Earth RAS \\ Bolshaya Gruzinskaya, 10, Moscow, Russia, 123995 \\ ${ }^{3}$ Geological Institute RAS \\ Pyzhersky lane, 7, Moscow, 119017
}

\begin{tabular}{l|l}
\hline & $\begin{array}{l}\text { Summary. Magnetic minerals of rocks are sensitive to the rock formation environment and } \\
\text { subsequent lifecycle. This sensitivity is reasoned by two cases: by variable iron valency and by } \\
\text { relative instability of the rocks formed within accumulation. For the study reasons, a number of } \\
\text { cross-sections were reviewed. The cross-section in Karaja which is located } 10 \mathrm{~km} \text { away from } \\
\text { Mingechevir town with coordinates } \lambda=47^{\circ} \mathrm{E}, \varphi=40^{\circ} \mathrm{N}, \text { is characterized by complete sequence of } \\
\text { Pleistocene sediments. The research of marine sediments was objective of the current study. The } \\
\text { mentioned section, by completeness and representativeness, is unique for paleomagnetic study of } \\
\text { Paleo-Caspian Basin. The abundance of fauna and layers of volcanic ash allow dating of the stud- } \\
\text { ied geological events. As a result of petro-magnetic researches, the regular relationship between } \\
\text { variations of magnetic parameters of rocks and transgressive-regressive sea level behavior of } \\
\text { Paleo-Caspian Basin was determined. These transgression-regression cycles were caused by tec- } \\
\text { paleomagnetism } \\
\text { tonic activity in the Caucasian region and by global climatic changes. } \\
\text { C } 2018 \text { Earth Science Division, Azerbaijan National Academy of Sciences. All rights reserved. }\end{array}$ \\
\hline
\end{tabular}

\section{Introduction}

Formation conditions of sedimentary rocks can be reflected in magnetic properties of the main magnetic minerals contained in these rocks. The article is devoted of the petro magnetic study of the Karaja section's marine terrace deposits, located approximately in $10 \mathrm{~km}$ away from town Mingechevir (Azerbaijan) (Mingechevir Reservoir, 470 E, 400 N) (Fig 1).The Karaja section is a unique object in terms of geological features' completeness and representativeness. The Karaja section refers to the folded zone BogazKaraja-Karamaryam and represents an anticline $17 \mathrm{~km}$ long anticline (Mamedov, Aleskerov, 2002). In the north of the monoclinic fold the complete deposit sequence is exposed (thickness about $1000 \mathrm{~m}$, fitting to Pleistocene).The top-most part (undisturbed) of Karaja section (associated with the middle and late Valdai interstadials $\sim 50-10 \mathrm{ka}$ BP) represents two marine terraces of Late Pleistocene age (Trubikhin, 1987). In this research paper the attention of authors is concentrated on horizontal sediments of the top marine terrace (Pilipenko et al., 2009).
The Pleistocene transgression's rhythmic character reflected in marine terraces had the glacioeustatic nature. The world ocean waters were accumulated in icecap and glaciers (during the cold periods) hereupon the ocean water level was reduced (regression). During the warmer periods a glaciers' melting led to increase the sea-level. As a result of tectonic activity (in Pleistocene) the Manych Strait (the passage connecting the Paleo Caspian Sea and Paleo Black Sea basins) was closed. As a result sea-level had been locally risen up to $70 \mathrm{~m}$. The gradual increase of the sea-level (In the Paleo Caspian basin) had led to transfusion of surplus water through the Manych isthmus (a barrier between the Paleo Caspian Sea basin and Paleo Black Sea basin). The sea-level had fallen till $30 \mathrm{~m}$ again after eroding of this barrier.

The marine terrace's structure perfectly reflects the periods of transgression/regression of the Paleo Caspian basin. It includes three sections. Two sections are the warm periods (transgression). Corresponding to the cold period (regression) the third 
section is placed between the two warm periods. This part of the marine terrace consists of sandstone, including rubble lenses and gravel ones. In the bottom of the marine terrace (the first transgression) the sediments consist of carbonatealeurolite deposit. In the top of terrace (second transgression) the marine subareal sediments consist of the sandy aleurolite and sandy loams. The regression period (corresponding to the cold period, i.e. sea-level decrease) is located between these two transgressions. Thickness of the studied stratigraphic section Karaja is about $13 \mathrm{~m}$.

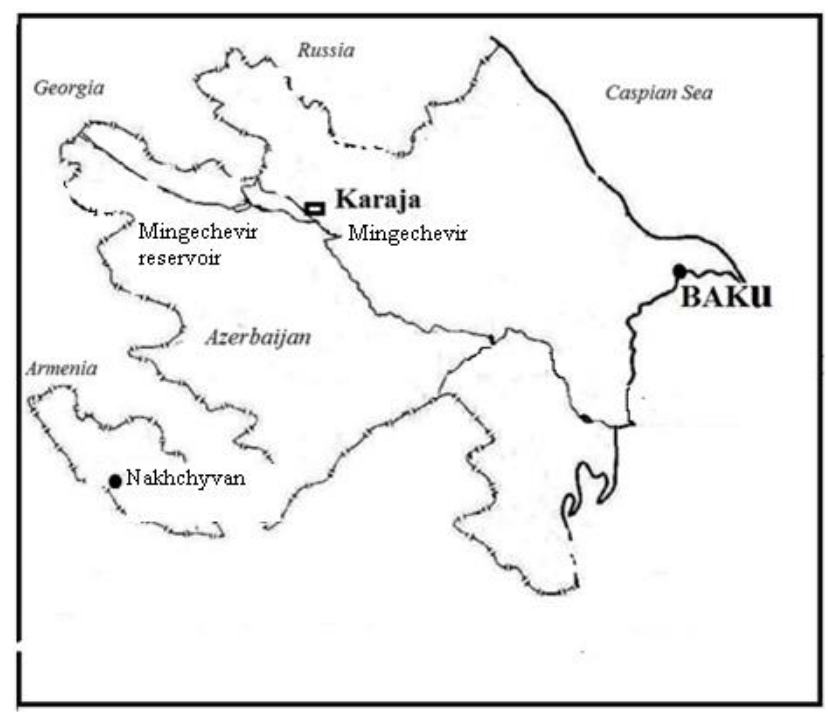

Fig. 1. Geographic position of the Karaja section

Late Pleistocene deposits of the Karaja section upper terrace are not defined by any dating of an absolute age. In this case the geological correlation of Karaja section deposits with well studied evenaged deposits of the Black Sea basin (Dodonov et al., 2000) allowed determining the age of the researched marine terrace deposits. As a result of the above mentioned geological correlation we have found out that the base of marine terrace of Karaja section (transgression) (consisting of carbonatealeurolites) corresponds to the oxygen-isotope stage 5. It means that the base of the Khvalynian marine terrace deposits corresponds to age as $\sim 45 \mathrm{ka} \mathrm{BP}$. The upper part of the Karaja's marine terrace corresponds to the oxygen-isotope stage 3 . It means that the upper part of a marine terrace of Karaja section coincides with middle Valdai age and corresponds to an age $\sim 20 \mathrm{ka} \mathrm{BP}$.

\section{Selection of the collection}

From the bottom to the top of Karaja section's marine terrace the hand blocks of carbonadealeurolite, sandy aleurolite and sandy loam deposits were collected by the method of continuous sam- pling. The hand blocks of a marine terrace correspond to two transgressions of the Paleo Caspian basin. Oriented along the magnetic meridian the hand blocks were sawed into horizontal plates. The latter were used to prepare oriented 2-cm cubic samples with three duplicates for each level. The number of levels of the marine terrace amounted to 406 .

\section{Methods}

To examine the ferromagnetic minerals of the Karaja section the temperature dependence of isothermal remanent magnetization curves were constructed. Also the magnitude of coercivity remanence $\left(\mathrm{B}_{\mathrm{cr}}\right)$ and the value of blocking temperatures $\left(\mathrm{T}_{\mathrm{b}}\right)$ were determined using well established complex magnetic methods. The experiments were conducted at the "Laboratory of main geomagnetic field and petromagnetizm" of RAS Institute of physics of the Earth, Moscow (Russia). By means of a thermomagnetic analysis of an isothermal remanent magnetization the composition of magnetic minerals was determined (magnetite, maghemite and haematite).

Along all profile of Karaja section the main magnetic parameters (such as low-field magnetic susceptibility $\mathrm{K}_{\mathrm{lf}}$, natural remanent magnetization NRM, saturation isothermal remanent magnetization SIRM, anhysteretic remanent magnetization ARM, coercivity of remanence $B_{c r}$ ) were measured (by step with 2-cm of interval).

As a rule, in samples the variation of magnetic minerals concentration can be monitored by measurering of low-frequency magnetic susceptibility and saturation isothermal remanent magnetization. For marine terrace sediments both ratios of maximum to minimum magnitudes of $\mathrm{K}_{\mathrm{If}}$ and SIRM are approximately $\sim 15$. The high values of low-frequency magnetic susceptibility and saturation remanent magnetization correspond to the sandy horizons. These sandy horizons correspond to the Paleo Caspian basin regressions. The waters of the paleobasin withdrew. And as a result coarse ferromagnetic particles have quantitatively been increased.

Experimental investigations of isothermal remanent magnetization (IRM) have allowed drawing conclusions about magnetic mineralogy of the samples, selected from each stratigrafic level. During step-bystep magnetization up to $1.5 \mathrm{~T}$ it has become clear that $90 \%$ of saturation isothermal remanent magnetization is acquired by samples prior the $0.3 \mathrm{~T}$. It allows assuming that the main carrier of natural remanent magnetization is low-coercivity mineral. It can be a magnetite or a maghemite. During step-by-step increase of magnetic field up to $1.5 \mathrm{~T}$, in some instances, the permanent increase of sample's magnetization is observed. It is bound with existence of high-coercivity minerals in these samples, such as hematite. 
In the samples the ratios of antiferromagnetic minerals versus ferrimagnetic ones have been estimated by the S-ratios ( $\left.\mathrm{S}=\mathrm{IRM}_{-03 \mathrm{~T}} / \mathrm{SIRM}\right)$ (King and Channell, 1991). The value of the $S$-ratio changes in the range of -0.54 to -0.95 in various parts of the section. The majority of the samples had values around $\mathrm{S}=-0.9$. This estimation has showed a dominant role of low coercivity minerals such as magnetite or maghemite. But in the horizons coinciding with the regression of the Paleo Caspian basin the $S$ changes from $S=-0.5$ to $S=-0.6$. These changes of $\mathrm{S}$ reflect a majority of a high coercivity mineral such as hematite. Such conclusion is supported by measurement of the coercivity of remanence $\left(\mathrm{B}_{\mathrm{cr}}\right) . \mathrm{B}_{\mathrm{cr}}$ varies between $\sim 60$ and $\sim 90 \mathrm{mT}$ in the same samples. As a whole for the all collection $\mathrm{B}_{\text {cr }}$ varies between $\sim 30$ and $\sim 40 \mathrm{mT}$.

By using the method of Lowrie (1990) the IRM experiments were also made on 34 samples of a pilot collection. In the samples, along the $\mathrm{X}$ orthogonal axis at $1.5 \mathrm{~T}$, along the $\mathrm{Y}$-axis at $0.5 \mathrm{~T}$ and finally along the Z-axis at $0.2 \mathrm{~T}$, an IRM was induced. Thereafter the IRM stepwise were thermally demagnetized, and measurement of the resultant remanence was made after each step. In all representative samples the dominant presence of a low coercivity of magnetic phase $(0.2 \mathrm{~T})$ (unblocking temperature $\mathrm{Tb}=580-620^{\circ} \mathrm{C}$ ) were revealed by the unblocking temperatures of the IRM. As a result the magnetite and slightly oxidized magnetite are revealed as the dominant magnetic mineral. In all curves there are also an inflection between $300^{\circ} \mathrm{C}$ and $400^{\circ} \mathrm{C}$. This can be attributed to the presence of maghemite, which undergo transformation into hematite during heating. The presence of a hematite is also affirmed by a higher coercivity unblocking temperature $\left(675^{\circ}\right.$. $700^{\circ} \mathrm{C}$ ).

As revealed by the various experiments magnetite, magemite and hematite are the dominant magnetic carriers of the remanence.

The ARM/SIRM, SIRM $/ \mathrm{k}_{\text {lf }}$ and $\mathrm{ARM} / \mathrm{k}_{\text {lf }}$ ratios were applied as grain size indicators of magnetite. In the Karaja section these ratios vary from 3 to 4 , indicating that the grain size variations in general are not very strong. For the researched horizons the ARM/SIRM-ratio and ARM/K $/$-ratio reveal the values, associated with the growth of the superparamagnetic particle concentration. The values of the frequency-dependent susceptibility $\mathrm{K}_{\mathrm{fd}}=$ $\left(\mathrm{k}_{\mathrm{lf}}-\mathrm{k}_{\mathrm{hf}}\right) \times 100 \% / \mathrm{k}_{\mathrm{lf}}$ are higher than $8 \%$. That means that the percentage of the super-paramagnetic particles is more than 50\% (Dearing, 1999).

The anisotropy of magnetic susceptibility (AMS) was used for checking of reliability of the NRM directions. The orientation of the remanence carriers can also be changed by any tilting of the sedimentary layers or their deformation. On 3 samples from the each level the AMS was measured prior to AF-demagnetization of the samples. Beginning from $\sim 10 \mathrm{~m}$ an increasing trend of $\mathrm{F}=\mathrm{Ky} / \mathrm{Kz}$ with depth is observed. This may relate to compaction of the loams. At the interval 8.4-8.8 $\mathrm{m}$ a sharper fall of $F$ is revealed.

In order to isolate the component (parallel and proportional to the geomagnetic field) that is coeval with sedimentation the stepwise alternating field demagnetization (AF) was carried out on representative samples. To isolate the primary magnetization component the 34 representative samples were subjected to a full (5-90 mT) stepwise AF demagnetization by step of $5 \mathrm{mT}$.

The majority of samples exhibit a secondary VRM overprint which was easily removed by moderate AF-demagnetization in alternating magnetic field. Also dominant samples exhibit a secondary (or overprint) stable ChRM which was educed at $25 \mathrm{mT}$. Samples of duplicates' collection from each 375 levels were demagnetized in alternating magnetic field. In samples that were demagnetized in the range 15$35 \mathrm{mT}$, main carriers of a remanent magnetization were minerals with a low coercivity. In samples that were demagnetized in the range of 35-60 mT main carriers of a remanent magnetization were minerals with a high coercivity.

\section{Results and discussion}

In the Karaja section for the depth intervals 3.65-3.74 $\mathrm{m}, 5.15-5.24 \mathrm{~m}, 8.58-8.69 \mathrm{~m}$ and 11.14$11.38 \mathrm{~m}$ the $\mathrm{D}$ - and I-values significantly deviate from the average.

The first diagnostic interval (from $3.65 \mathrm{~m}$ to $3.74 \mathrm{~m}$ ) covers 5 levels of the layer 19 in the upper part of the marine terrace. In this interval the inclination $I$ varies from $-7^{0}$ to $-54^{0}$ and the declination D varies from $101^{0}$ to $119^{\circ}$. The main carrier of magnetization is hematite. Low coercitivity and high coercitivity components have a same magnetization direction. The AMS measurements revealed that this section's interval has a normal sedimentary fabric.

The second diagnostic interval (from $5.15 \mathrm{~m}$ to $5.24 \mathrm{~m}$ ) reveals abnormal magnetization directions on 3 levels of the layer 17. In this interval the inclination $I$ falls down to $27^{\circ}$ and the declination $D$ equals to $190^{\circ}$. The main magnetization carrier is hematite. The AMS results show that there is no any tilting or deformation of the sedimentary layers.

The third interval (from $8.58 \mathrm{~m}$ to $8.69 \mathrm{~m}$ ) comprises 6 levels in layer 13 . Values of $I$ vary between $39^{\circ}$ and $57^{\circ}$ and $D$ - between $166^{\circ}$ and $187^{\circ}$. The scalar magnetic parameters show values for the low coercitivity minerals (such as magnetite or maghemite). The deviations of angle elements coincide with sharp 
variations of $F=K_{y} / K_{z}$ and $L=K_{x} / K_{y}$ parameters. Stereographic projections of the main axes of AMS ellipsoid show linear anisotropy which was caused by downslope movements of sedimentary layers. This could cause a rotation of the ChRM vector.

The fourth diagnostic interval (from 11.14 to $11.38 \mathrm{~m}$ ) covers 11 levels in layer 7 where $D$ deviates up to $167^{\circ}$. Thermomagnetic analysis displayed that hematite is the main carrier of the magnetization. There is an increasing trend of $F$ with depth up to the $10 \%$. This may be related with compaction of the loamsand. It is natural for a normal sedimentary fabric. Except the interval of $8.58 \mathrm{~m}$ to $8.69 \mathrm{~m}$, (samples showing an abnormal behavior) the main carrier of natural remanent magnetization possesses the hematite magnetic mineral. These interval deposits can be related with chemical oxidation processes and reflect the environmental and climate changes during the sediment deposition. Nevertheless, these samples possessed the abnormal direction of NRM at elementary measurements. Remanence did not reveal the direction of the dipole field for the local geographic site after AF-demagnetization. The two

\section{REFERENCES}

Dearing J. Magnetic susceptibility. In: Walden J., Smith J.P., Oldfield F. (Editors). Environmental Magnetism: a practical guide, Quaternary Research Association. Technical Guide, № 6, London 1999, pp. 35-62.

Dodonov A.E., Tchepalyga A.L., Mihailescu C.D., Zhou L.P., Markova A.K., Trubikhin V.M., Simahova A.N., Konikov E.G. Last-interglacial records from central Asia to the northern Black Sea shoreline: stratigraphy correlation. Netherlands Journal of Geosciences, V. 79, №2/3, 2000, pp. 303-311.

King J.W., Channell J.E.T. Sedimentary magnetism, environmental magnetism, and magnetostratigraphy. U.S. Nat. Rep. Int. Union Geod. Geophys. Rev. Geophys. 1987-1990, V. 29, 1991, pp. 358-370.

Lowrie W. Identification of ferromagnetic minerals in a rock by coercivity and unblocking temperature properties. Geophys. Res. Lett., V. 17(2), 1990, pp. 159-162.

Mammadov A.B., Aleskerov B.D. Pleistocene of Azerbaijan. Azerbaijan National Academy of Sciences. Institute of Geography. Baku, 2002, 70 p. (in Russian).

Pilipenko O.V., Sharonova Z.V., Trubikhin V.M., Novruzov Z., Karyagdy S.K., Abrakhamsen N. Study of environmental change of Karaja section rocks formation (Azerbaijan) on results of petromagnetic research. Earth Physics, № 4, 2009 , pp. 85-96 (in Russian).

Trubikhin V.M. Paleomagnetic method and dating of regional geological events of Pontian-Caspian. New data on geochronology of Quaternary period. Nauka. Moscow, 1987, pp. 150-157 (in Russian). very close directional components are illustrated by the Zijderveld diagrams: low coercivity components and high ones. We can reach a conclusion that the grains of magnetite and hematite were magnetized before transportation and compaction of the sediments. The detrital magnetic particles became aligned parallel to the Earth's magnetic field and acquired a detrital remanent magnetization during deposition and lithification. So we obtained the following age estimates for the diagnostic intervals: 1) interval from 3.65 to $3.74 \mathrm{~m}$ : $25 \mathrm{ka} \mathrm{BP}, 2)$ interval from 5.15 to $5.24 \mathrm{~m}$ : $\sim 29 \mathrm{ka} \mathrm{BP}$ and interval from 11.14 to $11.38 \mathrm{~m}: \sim 39 \mathrm{ka}$ BP. We regard these directional anomalies as evidence of reduced Mono Lake and Laschamp excursions.

As a result of petro-magnetic researches, the regular relationship between variations of magnetic parameters of rocks and transgressive-regressive sea level behavior of Paleo-Caspian Basin was determined. These transgression-regression cycles were caused by tectonic activity in the Caucasian region and by global climatic changes.

\section{ЛИТЕРАТУРА}

Dearing J. Magnetic susceptibility. In: Walden J., Smith J.P., Oldfield F., (Editors). Environmental Magnetism: a practical guide, Quaternary Research Association. Technical Guide, № 6, London, 1999, pp. 35-62.

Dodonov A.E., Tchepalyga A.L., Mihailescu C.D., Zhou L.P., Markova A.K., Trubikhin V.M., Simahova A.N., Konikov E.G. Last-interglacial records from central Asia to the northern Black Sea shore line: stratigraphy correlation. Netherlands Journal of Geosciences, V. 79, № 2/3, 2000, pp. 303-311.

King J.W. and Channell J.E.T. Sedimentary magnetism, environmental magnetism, and magnetostratigraphy. U.S. Nat. Rep. Int. Union Geod. Geophys. Rev. Geophys. 1987-1990, V. 29, 1991, pp. 358-370.

Lowrie W. Identification of ferromagnetic minerals in a rock by coercivity and unblocking temperature properties. Geophys. Res. Lett., V. 17(2), 1990, pp. 159-162.

Мамедов А.В., Алескеров Б.Д. Плейстоцен Азербайджана. Национ. Акад.наук Азербайджана. Институт Географии. Баку, 2002, 70 c.

Пилипенко О.В., Шаронова 3.В., Трубихин В.М., Новрузов 3., Карягды С.К., Абрахамсен Н. Изучение изменений среды формирования пород разреза Караджа (Азербайджан) по результатам петромагнитных исследований. Физика Земли, № 4, 2009, с. 85-96.

Трубихин В.М. Палеомагнитный метод и датирования региональных геологических событий Понто-Каспия. Новые данные по геохронологии четвертичного периода. Наука. Москва, 1987, с. 150-157. 


\title{
ТРАНСГРЕССИЯ И РЕГРЕССИЯ КАСПИЙСКОГО ПАЛЕОБАССЕЙНА ПО ПАЛЕОМАГНИТНЫМ ДАННЫМ
}

\author{
Новрузов 3.А. ${ }^{1}$, Пилипенко О.В. ${ }^{2}$, Трубихин В.М. ${ }^{3}$, Исмаил-заде Т.Т. ${ }^{1}$ \\ ${ }^{1}$ Институт геологии и геофизики НАНА (Азербайджан) \\ AZ1143, г.Баку, просп. Г. Джавида,119: znovruz@yahoo.com \\ ${ }^{2}$ Институт физики Земли РАН (Россия) \\ 123995, Россия, Москва, ул. Большая Грузинская, 10 \\ ${ }^{3}$ Геологический институт РАН (Россия) \\ 119017, Россия, Москва, Пьюевский пер., 7
}

Резюме. Магнитные минералы горных пород чувствительны к условиям их образования и последующей жизни. Эта чувствительность обусловлена двумя причинами: а) переменной валентностью железа; б) относительной неустойчивостью сформировавшихся пород серий минеральных твердых растворов в условиях залегания.

В разрезе Караджа (Азербайджан, примерно 10 км от г. Мингячевир, $\lambda=47^{0} \mathrm{E}, \varphi=40^{0} \mathrm{~N}$ ) обнажается полная последовательность плейстоценовых отложений. В основном плейстоценовые отложения сильно дислоцированы. Самая верхняя же часть отложений (50-10 тыс. лет), не дислоцирована и представляет собой две (верхняя и нижняя) морские террасы.

Объектом наших исследований были морские/лагунные отложения верхней морской террасы разреза Караджа. По полноте и представительности этот разрез является уникальным для палеомагнитного изучения Каспийского палеобассейна. Обилие фауны и наличие в разрезе прослоев вулканического пепла позволяет уверенно датировать изучаемые геологические события. В результате петромагнитных исследований была установлена закономерная связь между изменениями магнитных параметров пород и трансгрессивно-регрессивным поведением уровня моря Каспийского палеобассейна. Эти циклы трансгрессии-регрессии были вызваны тектонической активностью в Кавказском регионе и глобальными климатическими изменениями.

Ключевые слова: морской, лагунные отложения, плейстоиен, петромагнетизм

\section{PALEOMAQNIT MəLUMATLARI OSASINDA XəZəR PALEOHÖVZəSININ TRANSQRESSIYA Və REQRESSIYASI}

\author{
Novruzov Z.A. ${ }^{1}$, Pilipenko O.V. ${ }^{2}$, Trubixin V.M. ${ }^{3}$, İsmail-Zadə T.T. ${ }^{1}$ \\ ${ }^{1}$ AMEA Geologiya va Geofizika Institutu \\ AZ1143, Azarbaycan, Bakı şəh., H.Cavid prosp.,119: znovruz@yahoo.com \\ ${ }^{2}$ REA Yer təkinin Fizikası İnstitutu \\ 123995, Rusiya, Moskva şəh., Bolşaya Qruzinskaya küç., 10 \\ ${ }^{3}$ REA Geologiya Institutu \\ 1190177, Rusiya, Moskva şəh., Pljevskiy dönqə, 25
}

Xülasə. Süxurların maqnit mineralları öz formalaşmasına və sonrakı "həyat" şəraitlərinə həssasdır. Bu həssaslıq iki səbəbdəndir: a) dəmirin dəyişən valentliyindən; b) əmələ gələn mineral-sülb məhlullar seriyalarının yatım şəraitində nisbi dayanıqsızlı̆̆ından.

Qaraca kəsilişində (Azərbaycan, Mingəçevir şəhərindən təxminən $10 \mathrm{~km}, \lambda=47^{0} \mathrm{E}, \varphi=40^{\circ} \mathrm{N}$ ) Pleystosen çöküntüləri tam ardıcıllıgı ilə təmsil olunur. Pleystosen çöküntüləri əsasən güclü dislokasiyaya məruz qalmışdır.Qaraca kəsilişinin ən yuxarı hissəsi (üst Pleystosen çöküntüləri, 50-10 min il) dislokasiyaya məruz qalmamışdır və iki (yuxarı və aşağı) dəniz terrasından ibarətdir. Tədqiqat obyekti yuxarı dəniz terrasının dəniz/laqun çöküntüləri idi. Tamlığı və təmsilçiliyi ilə xarakterizə edilən bu kəsiliş PaleoXəzər hövzəsinin paleomaqnit məlumatları əsasında öyrənilməsi üçün unikaldır. Kəsilişdə fauna bolluğu və vulkanik kül təbəqəciklərinin mövcudluğu tədqiq olunan geoloji hadisələrin yaşını dəqiqliklə təyin etməyə imkan verir. Petromaqnit tədqiqatlar nəticəsində müəyyən edilmişdir ki, Paleo-Xəzər hövzəsində dəniz səviyyəsinin transqressiv-reqressiv dəyişilmələri ilə maqnit xassələrinin variasiyaları arasında məntiqi əlaqə var. Bu transqressiv-reqressiv tsıkllərə Qafqaz regionunda tektonik fəaliyyət və qlobal iqlim dəyişiklikləri səbəb olmuşdur.

Açar sözlor: dəniz, laqun çöküntülori, pleystosen, petromaqnetizm 